\title{
一臨床および実験報告一
}

\section{剖検にて高頻度にらい菌（M. LEPRAE）を確認し得た}

\section{ハンセン病（極性らい腫型）の 1 例}

\author{
矢島 幹久 ${ }^{11}$ 成田 稔 ${ }^{11}$ 山田 宣孝 ${ }^{21}$ 浅野 伍朗 ${ }^{31}$ \\ 1)国立療養所多䄷全生園 \\ ${ }^{2}$ 日本医科大学付属病院病理部 \\ ${ }^{3)}$ 日本医科大学病理学第 2 教室
}

An autopsy case of Hansen's disease (LLp) with numerous $M$. LEPRAE

\author{
Mikihisa Yajima ${ }^{1)}$, Minoru Narita ${ }^{1)}$, Nobutaka Yamada ${ }^{21}$ and Goro Asano ${ }^{33}$ \\ "National Leprosarium Tama-Zenshouen \\ ${ }^{2)}$ Division of Surgical Pathology, Nippon Medical School \\ ${ }^{3}$ Department of Second Pathology, Nippon Medical School
}

Key words : Hansen's disease, mycobacterium leprae, skin, peripheral nerve, pathology

\section{緒 言}

1996 年 11 月現在, 本邦のハンセン病療養所(国立 13 力所，私立 2 力所)には約 5,400名の入所者がいるが, その中の菌陽性者は約 $2 \%$ に過ざない!

ハンセン病と診断され, 長期の化学療法を経て, 臨 床的に消退期 3 期 $\left(\mathrm{Lr}_{3}\right)$ と診断され，大葉性肺炎にて 死亡したが，剖検にて広範な皮膚扔よび末梢神経にら い菌の存在を確認した症例を経験した。

化学療法, 特にジアフェニルスルフォン (DDS) リ ファンピシン (RFP) によるらい菌の耐性化抢よび菌 陰性化の判定基準の問題点を踏まえ, より正確な病 型・病期の決定やらい菌の検出法および治癒判定に, 従来の病巣部生検, 血清学的検査に加え, 近年開発さ れた PCR 法, 免疫組織化学的手法などを行い, 総合的 に判定する必要がある。

以上につき若干の考察を加え，報告する.

\section{症 例}

症例：61 歳, 男性. 出身地：長崎県.

家族歴：画親，兄弟（6名）にハンセン病と診断さ れた者はいない。

病歴：1952 年 (19 歳時), 右下腿外側皮膚火傷時に 疼痛がなく，その後，同部に皮疹が出現した。近医に
て約 1 年間，治療されたが改善なく，1954 年，国立療 養所菊池恵相園（ハンセン病療養所）に紹介され，入 所となる。約 2 年の加療後社会に復帰し，農業に従事 していたが, 1977 年頃より口唇下垂が出現し，次第に 口唇周国のしびれ感，右側頭部・下顎の違和感が増強 し，摂食時むせるようになってきた. 1979 年(46 歳時) には皮疮が出現し，菊池惠楓園に再度入所した。入所 当初は菌指数（bacterial index：以下 BI）に扔いてら い菌は㓌性であったが，1981年，左右前腕伸側皮疹部 に扔いてらい菌は陽性で，リファンプシン (RFP)，ジ アフェニルスルフォン (DDS) を投与され，1982 年に は菌陰性となる。これらの一連の症状は末梢神経麻痺 の進行と考えられ，1992 年には国立療廙所多磨全生園 に転園となる.1994 年10月，それまで園内住宅で生活 を送っていたが，らい性神経炎增德のため摂食拒否， 極度の栄養障害となり治療棟に入室した。

入室時現症: 身長 $164.5 \mathrm{~cm}$, 体重 $49.4 \mathrm{~kg}$, 体温 $36.8^{\circ} \mathrm{C}$, 脈拍 $74 /$ 分整, 呼吸数 $20 /$ 分, 血压 $128 / 90$ $\mathrm{mmHg}$, 意識は清明. 神経学的には稫幹部を除く頭頸 部・顔面・上下肢皮覤に知覚麻放があり，特に口唇周 囲のしびれ感, 右側頭部および下顎の違和感が増強し， 左下眼瞼下垂，左下口唇扝よび上口唇方形筋の機能低 下が認められた。味覚異常も確認された。

入室時検查所見：未梢血液所見では赤血球 $211, \mathrm{Hb}$. 5.5, Ht. 17.6, MCV 83.4, MCH 26.1 と小球性低色 㨞性解向が認められた。生化学的検查にて総蛋白 5.1 
$\mathrm{g} / \mathrm{d} l$, 電解質ではカリウム值が $2.3 \mathrm{mEq} / l$ と低值を示 し, 低栄養状態が疑われた。 また, 血清検査にて CRP が $13.7 \mathrm{mg} / \mathrm{d} l$ と高值を示した. 胸部 X 線写真では両 側の肺上葉に限局して結節状の石灰化を伴い収縮傾向 を示す陳旧性結核巣が認められた。他には尿検査にて 軽度の潜血（赤血球 $1 \sim 2 /$ 毎）以外に異常所見はみら れなかった。

入室後経過：入室後，輸液などにより低栄養状態は 改善した。その間, 実施した心電図検查では上室性期 外収縮と v 1 3 に QS pattern が認められ陳旧性前壁 中隔梗塞が疑われた。低カリウム血症, 末梢神経痛は 改善したが, 顔面, 手足の腫脹は持続し, 酒臭, 喫煙 後には喘鳴の増強が認められた。 入室 9 日目, 右膝部 の表皮の剝離があり, 膿性滲出液を認めた。次第に臥 床の時間が長くなり, 呼吸性アシドーシスがみられる ようになり, 呼吸不全にて 1994 年 11 月 19 日永眠(入 室後約 1 力月).

\section{主要剖検所見}

皮膚組織は足底部, 左右膝部, 手背部から採取され たが，そのいずれにも真皮に泡沫様の胞体を示すファ ゴソーム (らい細胞) の集簇がみられた。これらのら い腫性肉芽腫は足底部でもっとも顕著であり，表皮と 真皮のらい腫性肉芽腫との間の細胞浸潤の乏しい膠原 線維のみの菲薄な層（subepidermal clear zone）も消 失し, 比較的よく保たれた皮膚付属器周囲や小血管, 毛細血管の周囲，血管壁内および内皮細胞にも同様の らい細胞が多数確認された. 小血管では血管炎の像を 呈していた。抗酸菌染色(FITE) では, 組織球が桿菌で あるらい菌を領食し, 胞体内で多数増殖する像を認め た(写真 1, 2, 3). 真皮および皮下組織内の末梢神 経は萎縮を示しているが,らい菌は確認できなかった。

皮膚のもどし標本を用いた電子顕微鏡による観察で は, 真皮内の小血管の反応性に腫大した内皮細胞の細 胞質内に菌球状のらい菌の集簇像 (写真 4 ) やマクロ ファージのらい菌の貪食像を認めた.

その他の部位では, 精巣上体の血管壁に血管炎を伴 うらい菌の局在と同部の末梢神経内にもらい菌の局在 が確認された (写真 5, 6).

左右肺臓（左 $660 \mathrm{~g}$, 右 $450 \mathrm{~g}$ ) は肺胞内への線維素 の滲出, 好中球の浸潤, 肺胞壁の充血, 肺胞内への漏 出性出血を認め, 大葉性肺炎赤色肝変期を示した. 肉 眼的にも確認された右肺上葉結核巣は著しい石灰化を 示すが, 肉芽腫の形成はなく, 抗酸菌 (FITE) 染色も 陰性であった。

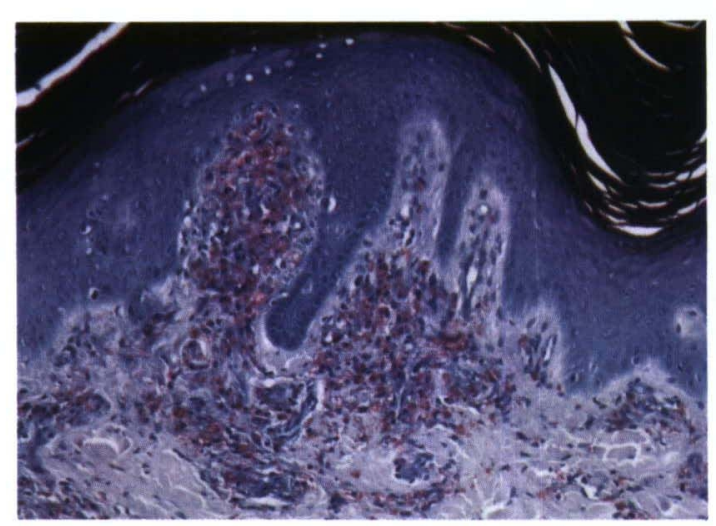

写真 1 足底部皮膚. 表皮直下の subepidermal clear zone が消失し, 真皮乳頭部以下の真皮全層に 菌の増殖および菌球形成も認められる (FITE 染色, $\times 40)$.

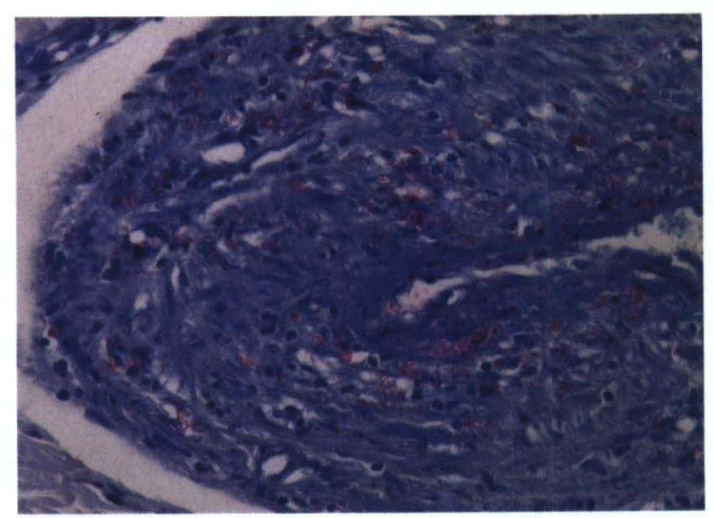

写真 2 足底部皮膚. 真皮動脈壁全体の菌球形成を伴 う菌の増殖が認められる(FITE 染色, $\times 200)$.

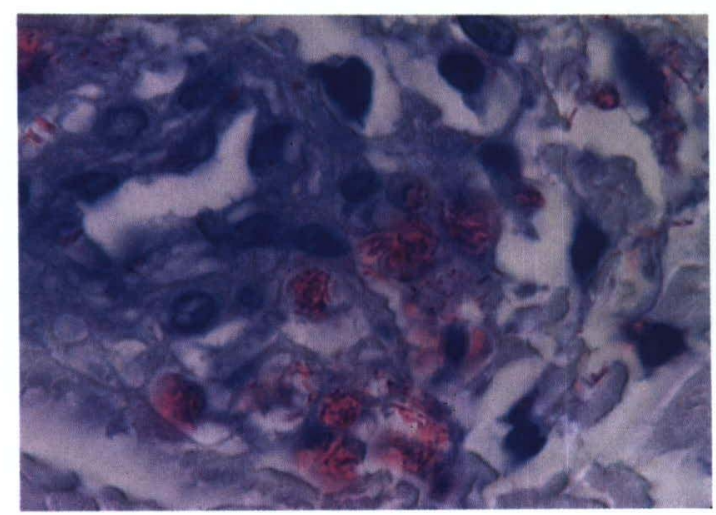

写真 3 足底部皮膚. 真皮小動脈および毛細血管には 内皮細胞の腫大と内皮細胞内拈よ゙゙その周囲 の菌の増殖を確認できる(FITE染色, $\times 1,000)$.

肝臓 $(1,850 \mathrm{~g})$ ではグリソン䩗と小葉中心性の線維 化を伴う脂肪肝をみるが，アルコール性硝子体は認め られなかった。また，心蔵 (350 g) の右室の拡張・肥 大に伴う諸臓器鬱血と腔水症が高度に認められた。 


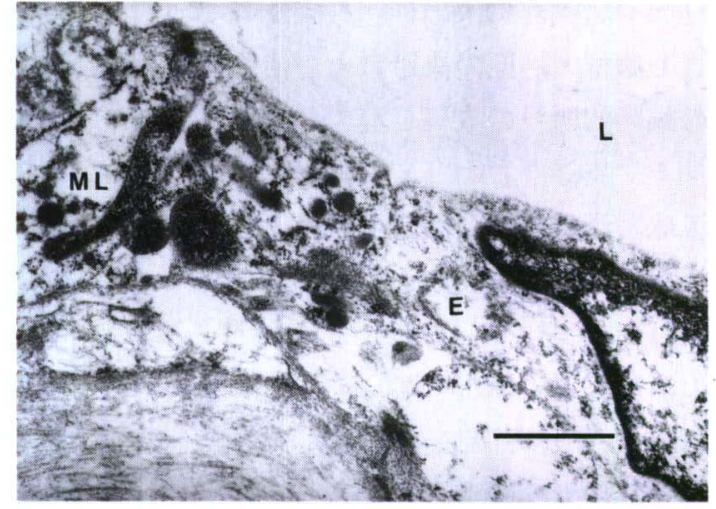

写真 4 電子顕微鏡的に真皮内の血管において反応性 に腫大した内皮細胞の細胞質内に菌球状のら い菌の集簇像が認められる. E : 内皮細胞, $\mathrm{L} ：$ 血管内腔, MR：細胞質内のらい菌の集 簇.

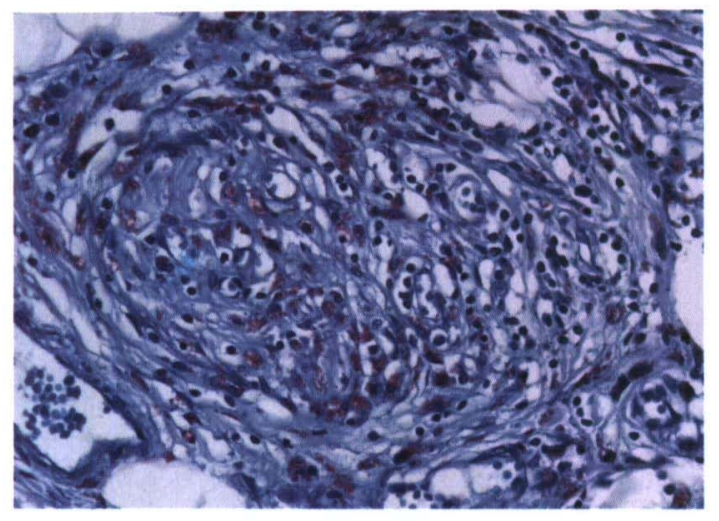

写真 5 精巣上体. 皮膚と同様に動脈壁全体の菌球形 成を伴う菌の増殖が認められる(FITE 染 色, $\times 1,000)$.

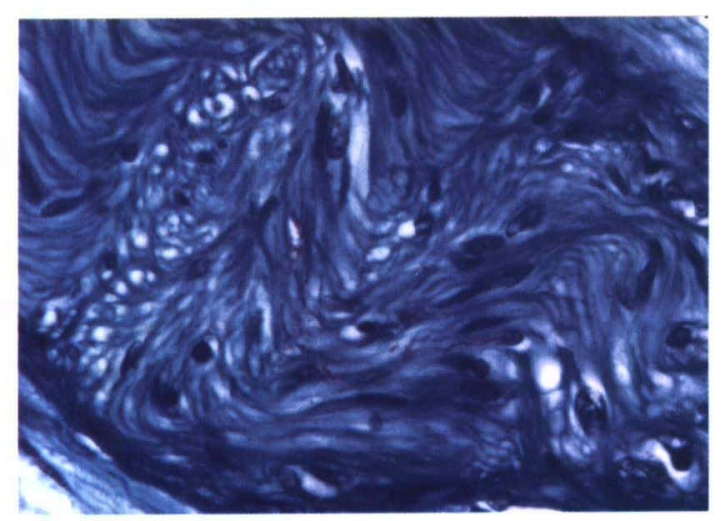

写真 6 精巣上体. 末梢神経束内に少数の菌が認めら れる (FITE 染色, $\times 1,000)$.

\section{考察}

ハンセン病は Ridley \& Jopling の分類で個体のら い菌に対する免疫能低下の程度により, らい腫型（le- promatous type : L), 類結核型 (tuberculoid type : T) と前記 2 型の中間である境界群（borderline group： B), 初期の未定型群 (indeterminate group : I) の 2 型 2 群に大きく分類されている2.

本症例は皮疹と知覚麻瘏により発症を自覚, 臨床的 に極性らい腫型 (lepromatous leprosy polar type) と診断され, その後, RFP, DDS をはじめとする複数 の抗ハンセン病薬を病初期より持続的に投与された. その結果, 死亡前には消退期 (retrogressive) の 3 期 と診断され, 浸潤や斑紋はよく吸収され, 神経の腫脹 はほとんど消退するか, または残存していても疼痛は ほとんどなく，菌指数（BI）は 1 ないし 0 であった.

しかし，剖検時に採取した足底部，左右膝部，手背 部のすべての皮膚にらい菌は局在し, 血管壁内にも菌 体が存在し，らい性血管炎の様相を呈していた。これ は抗ハンセン病薬, 特にDDS, RFP を長期にわたり持 続的に投与していたことに起因する耐性菌の出現と思 われる ${ }^{3}$.

ハンセン病の化学療法には 2 つの流れがある.ひと つはWHOの提唱する multi drug therapy (MDT) であり, 短期間に集中的な化学療法を行う治療プラン で, 世界中で推進されている. MDT は患者数が多く詳 細な診療が無理な地域でハンセン病の専門医がいなく ても化学療法を推進できるように考案された処方であ り耐性菌の出現も少ないが, 長くても 3 年の投薬の後, 異常があれば受診するように患者に説明し, 積極的な フォローアップを必要としていない. そのためか数少 ないながらも再発例が報告されている.

もう一つの方式はわが国を中心に行われてきた臨床 症状の消失と菌陰性化を目標とする従来からのやり方 である.この方式は臨床症状の消失と菌陰性化のあと, 少なくとも 2 年から 5 年間の DDS の内服が必要とな る.しかも, らい腫型の場合は菌に対する免疫不全が あるので再発への注意が必要であり, arrestになった 後も標準治療量の半量を一生服用し続けなければなら ない. DDS, RFP はどの病型においても耐性菌の出現 が大きな課題を残している. 詳細な観察による薬剤の 適宜増減, 急性の反応性病変や神経炎, 後遺症とそれ らに対する患者の理解とを考慮しながら治療を進める 必要がある1.

本症例では，病初期にDDS の誘導体であるプロミ ンを単独投与され，その後，約 30 年を経て RFP を併 用されている. DDSに耐性を有したらい菌に新たに RFP を併用しても単独投与と同じことになり,らい菌 はさらにRFPに耐性を生じる可能性が高くなる. RFP を併用する段階で同時に殺菌作用のあるオフロ 
キサシン (OFLX) や静菌作用と弱い殺菌作用のあるク ロファジミン (CLF) の併用投与も考えられた。

もう一つの問題点涃菌の陰性化の判定である。皮虞 からのSLIT-SMEAR 法により採取した塗沫標本を 抗酸菌染色を施し，100 倍の油漬レンズにて検鏡し， +1 から+6までの菌指数として表示するbacterial index が広く用いられているが，皮處生検材料による 切片標本に比べて，塗沫標本では菌濃度が明らかに小 さい4.特に菌が皮虞深部にのみ存在した場合には塗沫 標本だけで菌の存在を確認することはほとんど不可能 である。

近年，菌の同定の精度をより高めるため，皮疹部の 生検およびその一部を用いた PCR 法が以前にも増し てより推桨されている。また，局所の菌の同定だけで はなく血清学的検查が開発されてきている。

阿部ら ${ }^{5,6}$ は 1980 年, ハンセン病分野で初めて, 蛍光 抗体法 (FLA-ABS) を用い，ハンセン病を不顕性感染 の段階でコントロールすることを試みた。この研究が 契機となりモノクローナル抗体を活用した抗原検索に 関する数多くの研究が開始された。

Brennan ら 6,7 は 1980 年, らい菌種の特異的な糖脂 質抗原（PGL-I； phenolic glyco-lipid I）の存在を報告 した。また，PGL-Iに対するモノクローナル抗体が他 の 19 種の抗酸菌種と交差しないことが確認された。 PGL-I は単なる菌体成分ではなく，らい菌の感染組織 からも多量に精製される。菌の活発な分裂増殖に際し て多量证産生分泌され, 菌の生死と深い関わりを存っ 分泌型抗原と考えられ，らい菌にきわめて特異性が高 いことは広く認められている7。また，抗酸菌がつくる 多糖体である LAM-B (lipoarabinomannan-B) は抗酸 菌感染者の体内で特異抗原を産生するとされている. この血中抗体の測定はハンセン病に特異な反応ではな く，結核や非定型性抗酸菌が否定できる場合にはハン セン病の特異血清診断として意味がある8.

また，アンギオテンシン I を活性型のアンギオテン シンIIに変換するアンギオテンシンI変換酵素 (ACE) がハンセン病においても高值を示すことが報 告されている ${ }^{9}$.

治瘾と判定された後, 本症例のように数年を経ずし て再燃する例は後を絶たなかった。それは八ンセン病 の診断, 病型分類には, レプロミン反応, 菌指数 $(\mathrm{BI})$ の検査, 皮疹の性状, 知覚障害の程度, 未梢神経の肥 厚という臨床的所見が優位な診断基準として行わ水て きたからであり，治沜判定もそれらの改善・消失のみ を指標としてきた。しかし，著者山治淰と判定され， 他疾患で死亡したいくつかの剖検症例において，末梢
神経内や諸臓器に菌の存在を確認している。

真の病型・病期の決定および治癒判定のためには従 来の臨的所見の改善と消失に重点を扔いた判定基準 に加え，皮疮部および末梢神経生検にてらい菌および 組織球浸潤の有無の確認, 生検組織の一部を材料とし てのPCR 法に扔ける抗原量(約6力月の治療経過で 消失), 血清学的に PGL-I, LAM-B O抗体価(約6力 月の治療経過で検出下限),アンギオテンシンI変換酵 素测定 (ACEカラー法: 正常平均值; 20.7, 上昇傾 向；25.4, 上昇確実： $31.2 \mathrm{U} / \mathrm{m} l)$ などを積極的に行 い，総合的に判定する必要があると考える。

\section{結 論}

42 年前にハンセン病と診断され，陳旧性肺結核症に 大葉性肺炎を併発, 死亡時, 消退期 3 期 $\left(\mathrm{Lr}_{3}\right)$ と診断 されたが，皮䖉扔よび一部の末梢神経に広範ならい菌 の存在を確認した剖検例を経験したので若干の考察を 加え報告した。

\section{文 献}

1. 厚生省・財団法人藤楓協会編：ハンセン病診断・治療 指針. 1997 .

2. Classification Committee of Madrid Congress: Madrid Classification of leprosy. Draft report of Classification committee. Memoria del VI congreso internacional de leprologia. Octubre de 1953 ; pp7580, Madrid.

3. 中村一成：マウス足蹠法でみられた治らい剤耐性菌, 主としてDDS耐性菌について. 日らい会雑誌 1970 ; $39: 120$.

4. Sugiyama K, Izumi S: Electron microscopicbasis of the morphologic index. Int J Lepr $1973 ; 41: 1-6$.

5. Abe M, Minagawa F, Yoshino Y, Ozawa T, Saikawa K, Saito T: Fluoresent leprosy antibody absorption (FLA-ABS) test for detecting subclinical infection with Mycobacterium leprae. Int J Lepr $1980 ; 48: 109$.

6. 皆川文重：広範国血液・尿化学検查. 免疫学的検查(下 巻)：その数值をどう読むか：らい菌.日本臨床 1995 ； 53:224-226.

7. Brennan PJ, Barrow WW: Evidence for speciesspecific lipid antigens in M. leprae. Int J Lepr 1980 ; 48: 109

8. Butt KL, Kawatsu K, Wang T, Maeda Y, Izumi S : Immunopathological stain of lipoarabinomannan B(LAM-B) for diagnosis of leprosy. Jpn J Lepr 1993 ; $62: 13-20$.

9. Lieberman J, Rea TB: Serum angiotensin-converting enzyme in leprosy and coccidioidomycosis. Annals Int Med $1977 ; 87: 422-425$. 